\title{
Studi Farmakoepidemiologi Vitamin Penambah Darah Pada Ibu Hamil Di Kecamatan Jatinangor
}

\author{
Irma Rismayanti Amanah ${ }^{1}$, R. Tina Dewi Judistiani ${ }^{2}$, Enny Rohmawaty ${ }^{3}$ \\ Fakultas Kedokteran Universitas Padjadjaran, Bandung ${ }^{1,2,3}$ \\ irmarismayanti2406@gmail.com ${ }^{1}$
}

\begin{abstract}
Diajukan 24 Maret 2019 Diperbaiki 27 Mei 2019 Diterima 19 Agustus 2019
\section{ABSTRAK}

Pendahuluan: Prevalensi anemia defisiensi besi pada ibu hamil di dunia menurut WHO berkisar 35$37 \%$, hal serupa ditemukan pada ibu hamil di Indonesia, Riskesdas tahun 2013 melaporkan prevalensi tersebut pada angka $37,1 \%$. Meskipun pengobatan anemia defisiensi besi untuk ibu hamil telah masuk dalam pengobatan ANC, prevalensi tersebut belum memberikan hal yang diharapkan. Namun demikian di Kab Sumedang angka prevalensi anemia ibu hamil tahun 2016, lebih rendah, yakni $9,69 \%$, data farmakoepidemiologi terkait penggunaan vitamin penambah darah di Jatinangor masih terbatas (belum pernah dilakukan) penelitian ini dilakukan di Jatinangor sebagai daerah binaan Universitas Padjadjaran.

Tujuan: Tujuan penelitian mengetahui praktik konsumsi vitamin penambah darah pada ibu hamil di Kecamatan Jatinangor.

Metode: Penelitian potong lintang dilakukan bulan Juli-agustus 2018 dengan ibu hamil yang bertempat

sampel deskriptif sedangkan pengambilan sampel dilakukan di 12 desa dan subjek dipilih secara konsekutif. Analisis data dilakukan secara deskriptif data wawancara dilakukan menggunakan kuesioner tertutup.

Hasil: dalam kurun waktu penelitian tercatat 532 ibu hamil. Sebanyak 110 ibu hamil memenuhi syarat untuk ikut serta. Ditemukan 96 ibu hamil mengonsumsi vitamin penambah darah, 69 Mengonsumsi asam folat, 27 mengonsumsi Tablet zat besi, 15 mengonsumsi B12, 2 mengonsumsi B6. Ditemukan yang tidak minum vitamin, 14 ibu hamil dengan beberapa alasan, 8 orang merasa sehat-sehat saja, 3 orang merasa keluhan yang diderita ringan sehingga tidak memerlukan vitamin, 4 orang lainnya takut dengan efek samping yang ditimbulkan.

Kesimpulan: sebagian besar ibu hamil yang mengonsumsi suplemen vitamin penambah darah sudah sesuai dengan anjuran tenaga kesehatan.
\end{abstract} tinggal di Jatinangor berdasarkan rumus besar

Kata Kunci: anemia; tablet fe; suplemen

\section{ABSTRACT}

Introduction: The prevalence of iron deficiency anemia in pregnant women in the world according to WHO ranges from $35-37 \%$, similarly found in pregnant women in Indonesia, Riskesdas in 2013 reported a prevalence of $37.1 \%$. Although the treatment of iron deficiency anemia for pregnant women has been entered into ANC treatment, the prevalence has not given the expected thing. However, in Sumedang District, the prevalence of anemia in pregnant women in 2016 lower, 9.69\%, pharmacoepidemiological data related to the use of blood boosting vitamins in Jatinangor is still limited. this research was conducted in Jatinangor as target area of Universitas Padjadjaran.

Objective: To know the blood Enhancer supplement consumption practices on pregnant women in Jatinangor. Methods: A cross-sectional study was carried out in July-
August 2018 with pregnant women in Jatinangor, based on the formula large sample descriptive, sampling conducted in 12 villages and subjects were selected consecutively. Data analysis was carried out descriptively interview data using a closed questionnaire.

Results: within research recorded 532 pregnant woman, 110 pregnant women are eligible to participate. It was found 96 pregnant women taking blood boosting vitamins, 69 Taking folicacid, 27 taking irontablets, 15 consuming B12, 2 consuming B6. It was found who did not take vitamins, 14 pregnant women for several reasons, 8 people felt healthy, 3 people felt the complaints were mild so it does not require vitamins, 4 others were afraid of the side effects.

Conclusion: Most of the respondents already know how to consume suplments

Keywords: anemia, fe tablets, supplements 


\section{PENDAHULUAN}

Prevalensi Anemia di dunia menurut (WHO) ibu hamil yang mengalami defisiensi besi sekitar 35-37\%, sedangkan prevalensi anemia pada ibu hamil di Indonesia menurut Riset Kesehatan Dasar (Riskesdas) tahun 2013 sekitar $37,1 \%$ sedangkan di Kabupaten Sumedang sendiri prevalensi anemia pada tahun 2016 sekitar 9,69\% pada umumnya penyebab anemia bisa disebabkan oleh kekurangan nutrisi atau defisiensi mikronutrien (besi, folat, dan vitamin B12) akan tetapi ada beberapa faktor lain seperti konsumsi obat-obatan, adanya perdarahan, simpanan besi yang buruk dan sebagainya juga turut dalam menentukan status anemial-3. Anemia dapat menyebabkan, peningkatan curah jantung, peningkatan resiko perdarahan, dan penurunan kemampuan untuk mentolenransi kehilangan darah, yang dapat menyebabkan syok dan kematian, pada bayi bisa terjadi berat bayi lahir rendah (BBLR), kelahiran premature, hingga menyebabkan kematian perinatal, dan pada saat nifas dapat terjadi perdarah postpartum ${ }^{3,4}$

Anemia adalah kondisi konsentrasi hemoglobin yang kurang dari $12 \mathrm{~g} / \mathrm{dl}$ pada wanita tak hamil, dan kurang dari $10 \mathrm{~g} / \mathrm{dl}$ selama kehamilan atau masa nifas.4 Anemia adalah penurunan konsentrasi hemoglobin, faktor yang memengaruhi hemoglobin ada berbagai macam antara lain rendahnya asupan zat gizi (asupan protein, zat besi, dan vitamin C), protein berperan penting dalam transportasi zat besi didalam tubuh.5 rendahnya ibu hamil dalam mengkonsumsi suplemen penambah darah merupakan salah satu angka penyebab terjadinya prevalensi anemia masih tinggi.

Farmakoepidemiologi adalah ilmu mengenai penggunaan obat dan efek obat dalam populasi di daerah tersebut studi ini berguna untuk mengetahui pola penggunaan suplemen penambah darah pada ibu hamil.6 Suplemen tablet Fe adalah salah satu program pemerintah sejak tahun 1970 dalam pencegahan dan penanggulangan anemia defisiensi besi pada ibu hamil yaitu pemberian tablet zat besi sebanyak 90 tablet selama periode kehamilan. World Health Organization merekomendasikan agar suplemen zat besi diberikan kepada ibu hamil yang memiliki cadangan besi sebanyak 30-60 mg per hari dan untukibu hamilyang tidak memiliki cadangan besi sebanyak 120-140 mg per hari. ${ }^{6,7}$ Secara nasional cakupan ibu hamil mendapat tablet Fe tahun 2014 sebesar 85,1\%, data tersebut belum mencapai target program tahun 2014 sebesar 95\%. Sedangkan di Jawa Barat sendiri cakupan ibu hamil yang mendapat tablet Fe tahun 2014 sebesar 90,5\%. ${ }^{1}$ sedangkan di Kabupaten Sumedang tahun 2016 cakupan ibu hamil yang mendapat Tablet Tambah Darah (TTD) 90 tablet atau $\mathrm{Fe} 3$ mencapai $96,56 \%{ }^{4}$

Di negara berkembang, meskipun pemberian suplemen zat besi juga megandung asam folat namun defisiensi vitamin seperti vitamin A, asam folat dan vitamin B12 dapat menyebabkan anemia. Asam folat dan vitamin B12 diperlukan dalam pembentukan sel darah merah. Kekurangan asam folat dalam kehamilan akan menyebabkan gangguan pematangan inti eritrosit, sehingga muncul sel darah merah dengan bentuk dan ukuran abnormal yang disebut dengan anemia megaloblastic. ${ }^{9}$

Berdasarkan penelitian yang dilakukan oleh Aries 2017 bahwa 35 responden didapatkan rata-rata kadar hemoglobin pada ibu hamil sebelum mengonsumsi suplemen zat besi adalah 11,7 gr/dL dan kadar hemoglobin sesudah megonsumsi suplemen zat besi 12,0gr/dL, hal ini menunjukan bahwa terdapat perubahan kadar hemoglobin pada ibu hamil setelah mengonsumsi suplemen zat besi di Wilayah kerja Puskesmas Pesantren di Kota Kediri. 7 Hasil penelitian Amy G. al. (2015) menunjukan adanya pengaruh mengonsumsi rutin suplemen zat besi terhadap kadar hemoglobin pada ibu hamil di U.S. ${ }^{8}$

Peneliti dari Bangladesh bernama Ziauddin Hyder meneliti apa saja keluhan yang dirasakan ibu hamil setelah mengonsumsi tablet zat besi di daerahnya. Sampel yang 
digunakan dalam penelitiannya sebanyak 209 ibu hamil. Dari jumlah sampel tersebut, 82\% atau setara dengan 172 ibu hamil pernah merasakan efek samping dari tablet zat besi seperti heartburn, mual, muntah, diare, dan konstipasi.9

Penelitian lain dilakukan di daerah Ismailia oleh Ahmed dkk dalam menentukan faktor apa saja yang berpengaruh terhadap kepatuhan ibu hamil mengonsumsi tablet zat besi dan efek samping merupakan salah satu faktor yang berpengaruh. Penelitian tersebut menggunakan sampel ibu hamil sebanyak 100 orang. Efek samping yang dirasakan oleh ibu hamil adalah konstipasi, mual, muntah, heartburn, sakit perut, dan pusing. Dari beberapa efek samping tersebut, yang paling sering dirasakan yaitu konstipasi dengan prosentase sebanyak 35\% .10 Berbeda dengan hasil yang didapatkan oleh Ahmed, penelitian dilakukan oleh Ugwu et al., di Kota Enugu Negeria dengan jumlah sampel 420 responden. Dari beberapa efek samping tablet zat besi (konstipasi, diare, mual, muntah, heartburn, sakit perut dan pusing), keluhan yang paling sering dirasakan adalah heartburn. Efek samping sendiri menyebabkan ketidakpatuhan dengan prosentase $23,8 \% 11$

Dalam penelitian ini digunakan studi farmakoepidemiologi mengenai suplemen penambah darah. Berdasarkan latar belakang diatas, peneliti tertarik untuk melakukan penelitian lebih lanjut di Kecamatan Jatinangor yang bertujuan untuk mengetahui praktik konsumsi suplemen penambah darah pada ibu hamil di Kecamatan Jatinangor.

\section{METODE}

Penelitian ini menggunakan metode deskriptif kuantitatif dengan menggunakan pendekatan potong lintang. Populasi dalam penelitian ini adalah seluruh ibu hamil di Kecamatan Jatinangor Kabupaten Sumedang. Pengambilan sampel dilakukan di 12 desa subjek dipilih secara konsekutif. Setelah pembulatan besar sampel didapatkan $110 \mathrm{ibu}$ hamil. Analisis data dilakukan secara deskriptif data wawancara dilakukan menggunakan kuesioner tertutup.

\section{HASIL DAN PEMBAHASAN}

Berdasarkan hasil penelitian telah dilakukan wawancara terhadap 110 responden diantaranya terdapat 14 responden yang tidak megonsumsi sumplemen, dan pengambilan sampel dihentikan setelah didapat 96 sampel yang mengonsumsi suplemen.

Tabel 1 Distribusi Frekuensi Karakteristik Responden

\begin{tabular}{lcc}
\hline $\begin{array}{l}\text { Karakteristik } \\
\text { Responden }\end{array}$ & F & \% \\
\hline $\begin{array}{l}\text { Kelompok Usia } \\
<20 \text { tahun }\end{array}$ & 2 & 3 \\
20-35 tahun & 92 & 83 \\
$>35$ tahun & 16 & 14 \\
Pekerjaan & & \\
Bekerja & 32 & 30 \\
Tidak Bekerja & 78 & 70 \\
Pendidikan & & \\
Terakhir & & \\
SD & 8 & 8 \\
SLTP & 46 & 41 \\
SLTA & 52 & 47 \\
PT & 4 & 4 \\
\hline \multicolumn{1}{c}{ Jumlah } & $\mathbf{1 1 0}$ & $\mathbf{1 0 0}$ \\
\hline
\end{tabular}

Menurut hasil yang diperoleh dapat dilihat bahwa responden yang tidak mengonsumsi suplemen sebanyak 14 responden. Alasan responden tidak mengonsumsi suplemen diantaranya responden merasa sehat-sehat saja, merasa keluhan yang diderita ringan sehingga tidak memerlukan suplemen serta takut dengan efek samping, dapat dilihat bahwa sebagian besar (80 Responden) berada dalam rentang usia hamil yang aman karena berusia 20-35 tahun (Tabel 1). temuan tersebut tidak jauh berbeda dengan hasil penelitian Puti (2014) yang menganalisis data Riskesdas 2013 yaitu sebesar $80 \%$ ibu hamil berada dalam rentang usia yang aman menurut (BKKBN, 2011) usia 20-35 tahun merupakan usia aman atau ideal perempuan untuk hamil karena sudah bisa dikatakan siap fisik (terutama rahim), siap mental, emosional, psikologis dan siap secara sosial ekonomi. ${ }^{21}$

Responden termasuk kategori berisiko jika berusia terlalu muda (dibawah 20 tahun) 
dan terlalu tua (di atas 35 tahun). Pada perempuan dengan umur pertama haid yang masih muda, dan melakukan perkawinan dibawah umur akan membuat panjang rentang usia reproduksi perempuan dan berdampak pada banyaknya anak yang dilahirkan serta belum maturnya organ reproduksi perempuan sehingga dapat terjadi komplikasi pada saat persalinan. Ibu hamil diatas 35 tahun masuk kategori kehamilan berisiko karena pada usia tersebut organ kandungan menua dan jalan lahir kaku. Hal tersebut meningkatkan kemungkinan ibu hamil mengalami pendarahan saat proses persalinan dan bayi lahir cacat $^{21}$ penelitian yang dilakukann oleh Puspitaningrum (2013) juga memberikan hasil serupa dimana sebagian besar ibu hamil berumur antara 20-35 tahun. ${ }^{13}$

Tabel 2 Distribusi Frekuensi Karakteristik suplemen

\begin{tabular}{lcc}
\hline Jenis suplemen & F & $\%$ \\
\hline Merk dagang & & \\
suplemen & 80 & 83 \\
Generik & 16 & 17 \\
Non Generik & & \\
& & \\
Bentuk sediaan & & \\
suplemen yang & & \\
disukai & 32 & 33 \\
Kapsul & 15 & 16 \\
Pil & 46 & 48 \\
Tablet & 3 & 3 \\
Sirup & & \\
Bentuk sediaan & & \\
suplemen yang & & \\
digunakan & & \\
Kapsul & 33 & 34 \\
Pil & 15 & 16 \\
Tablet & 48 & 50 \\
& & \\
\hline Jumlah & $\mathbf{9 6}$ & \\
\hline
\end{tabular}

Berdasarkan jenis suplemen yang dikonsumsi responden seluruh responden sudah mengonsumsi tablet zat besi kombinasi yang didalamnya terdapat multivitamin dan mineral. Sebanyak $50 \%$ bentuk yang disukai dan digunakan responden adalah bentuk tablet sesuai dengan Permenkes No 88 Tahun 2014 komposisi didalamnya sekurangnya mengandung Zat besi setara dengan $60 \mathrm{mg}$ besi elemental (dalam bentuk sediaan ferro Sulfat, ferro fumarat atau ferro Gluconat) dan asam folat 0,25 mg. spesifikasi produk warna merah tua, bentuk bulat lonjong. ${ }^{14}$

Tabel 3 Distribusi frekuensi prilaku konsumsi dan sumber informasi suplemen.

\begin{tabular}{|c|c|c|}
\hline PolaPenggunaan Suplemen & $\mathbf{F}$ & $\%$ \\
\hline \multicolumn{3}{|l|}{ Suplemen mulai diminum } \\
\hline Trimester 1 & 69 & 72 \\
\hline Asam folat & 69 & 72 \\
\hline B6 & 2 & 3 \\
\hline B12 & 5 & 7 \\
\hline Trimester 2 & 18 & 19 \\
\hline B12 & 10 & 55 \\
\hline Tablet Zat Besi & 18 & 100 \\
\hline Trimester 3 & 9 & 9 \\
\hline Tablet Zat Besi & 9 & 100 \\
\hline Kalsium & 6 & 66 \\
\hline \multicolumn{3}{|l|}{ Waktu meminum Suplemen } \\
\hline Pagi hari & 3 & 3 \\
\hline Siang hari & 1 & 1 \\
\hline Sore hari & 1 & 1 \\
\hline Malam hari & 91 & 95 \\
\hline \multicolumn{3}{|l|}{ Media yang digunakan } \\
\hline Air putih & 94 & 98 \\
\hline Pisang & 2 & 2 \\
\hline \multicolumn{3}{|l|}{$\begin{array}{l}\text { Sumber memperoleh } \\
\text { suplemen }\end{array}$} \\
\hline Apotek & 1 & 1,0 \\
\hline Klinik/RS & 11 & 11 \\
\hline Puskesmas & 13 & 13 \\
\hline Bidan & 69 & 72 \\
\hline Dokter & 2 & 2 \\
\hline \multicolumn{3}{|l|}{ Sumber informasi } \\
\hline Dokter spesialis/dokter umum & 3 & 3 \\
\hline Bidan/perawat & 93 & 97 \\
\hline
\end{tabular}

\begin{tabular}{lcc}
$\begin{array}{l}\text { Konsultasi dengan nakes } \\
\text { setelah menggunakan }\end{array}$ & \\
suplemen & 70 & 73 \\
Ya & 26 & 27 \\
Tidak & & \\
$\begin{array}{l}\text { Alasan penggunaan } \\
\text { suplemen }\end{array}$ & 94 & 98 \\
$\begin{array}{l}\text { Anjuran Nakes } \\
\text { Inisiatif sendiri }\end{array}$ & 2 & 2 \\
Lupa minum suplemen & & \\
Ya & 72 & 75 \\
Tidak & 24 & 25 \\
\hline Jumlah & 96 & $\mathbf{1 0 0}$ \\
\hline
\end{tabular}

Hasil penelitian menunjukan bahwa masih terdapat ibu hamil yang baru meminum suplemen di trimester 2 dan 3 sebanyak $28 \%$ 
dan belum memenuhi suplemen multimikronutrien (MMN) mengandung 30 mg besi, 400 mikrogram asam folat, 800 mikrogram retinol, 200 IU vitamin D, 10 miligram vitamin $\mathrm{E}, 70$ miligram vitamin $\mathrm{C}, 1,4$ miligram vitamin B1, 18 miligram vitamin B3, 1,9 miligram vitamin $B 6,2,6$ mikrogram $B 12,15$ miligram seng, 2 miligram tembaga, 6,5 mikrogram selenium dan 150 mikrogram iodine (Sumarmi, 2014)..$^{22}$ Asupan zat besi yang tidak memenuhi kebutuhan akan menyebabkan ketidakseimbangan sehingga mengganggu pertumbuhan sel darah merah ibu. ${ }^{22}$ Studi yang dilakukan oleh Patimah, et al., (2013) menyatakan bahwa selama 12 minggu, ibu hamil yang mengonsumsi (MMN), kadar hemoglobinnya meningkat sebesar 0,91\% g/dl sedangkan ibu hamil yang mengonsumsi besi folat meningkat $0,54 \% \mathrm{~g} / \mathrm{dl} .^{21}$

Hasil penelitian menunjukan bahwa sebagian besar responden mengonsumsi suplemen vitamin penambah darah pada malam hari dan sebagian responden sudah mengetahui cara meminum tablet Fe dengan benar. Hal ini dibuktikan dengan jawaban responden yaitu sebanyak 94 responden meminum tablet Fe menggunakan air putih. Hasil diatas sesuai dengan teori Almatsier waktu yang tepat untuk minum tablet $\mathrm{Fe}$ adalah pada malam hari menjelang tidur, untuk mengurangi rasa mual yang timbul setelah meminumnya. Data diatas juga sesuai dengan teori Almatsier bahwa tablet Fe sebaiknya diminum dengan menggunakan air jeruk atau air putih, karena dapat membentuk proses penyerapan zat besi dan tidak menghalangi interaksi antara obat dengan penyerapan zat besi. ${ }^{17}$ Hasil penelitian menunjukan bahwa informasi penggunaan suplemen vitamin penambah darah sebagian besar responden mendapatkan dari bidan brerdasarkan penelitian yang dilakukan oleh Handayani pada tahun 2013 menyatakan bahwa peran petugas kesehatan harus mampu sebagai komunikator dan fasilitator. Petugas harus memberikan informasi secara jelas kepada pasien. Pemberian informasi sangat diperlukan karena komunikasi diperlukan untuk mengkondisikan faktor kurangnya pengetahuan dan sikap masyarakat terhadap kesehatan dan penyakit. Untuk itu diperlukan komunikasi yang efektf dari petugas kesehatan terutama bidan. Bidan sebagai fasilitator juga harus dilengkapi dengan buku pedoman pemberian tablet besi dengan tujuan agar petugas mampu melaksanakan pemberian tablet besi pada kelompok sasaran dalam upaya menurunkan prevalensi anemia karena peran bidan sangat mempengaruhi ibu dalam mengonsumsi tablet Fe. ${ }^{15}$

Tabel 4 Distribusi frekuensi efek samping penggunaan suplemen.

\begin{tabular}{lcc}
\hline Efek samping & F & \% \\
\hline Sulit BAB & 7 & 7,3 \\
Mual & 52 & 54,2 \\
Muntah & 1 & 1,0 \\
Pusing & 4 & 4,2 \\
Tidak ada keluhan & 32 & 33,3 \\
\hline Jumlah & $\mathbf{9 6}$ & $\mathbf{1 0 0}$ \\
\hline
\end{tabular}

Hasil penelitian menunjukan bahwa sebagian responden mengalami efek samping seperti mual dan konstipasi yang sering timbul setelah mengonsumsi tablet zat besi penelitian ini sesuai dengan penelitian yang dilakukan oleh Irvina yang menyatakan sebanyak 58\% responden $(64,4 \%)$ merasakan efek samping setelah meminum tablet Fe. Beberapa efek samping yang dirasakan responden yaitu mual muntah, konstipasi, diare, pusing, dan sakit perut. Hasil tersebut juga sesuai dengan penelitian sebelumnya di Asahan Sumatera Utara tentang efek samping yang dirasakan ibu hamil setelah meminum tablet Fe. Efek samping umum yang biasanya ditimbulkan oleh Fe yang diberikan secara per oral yaitu mual muntah, konstipasi, diare dan sakit perut. Sebanyak $7,3 \%$ responden menyatakan bahwa mereka mengalami konstipasi setelah meminum tablet Fe. Hasil penelitian ini tidak jauh berbeda dengan hasil peneitian sebelumnya di Ismalia Mesir.

Hasil penelitian menunjukan bahwa sebagian responden $75 \%$ pernah lupa minum 
suplemen vitamin penambah darah dan juga sebanyak $45,8 \%$ pernah mengurangi atau berhenti minum suplemen tanpa sepengetahuan petugas kesehatan (dokter/bidan/perawat) dan terdapat 8,3\% merasa terganggu harus minum suplemen vitamin penambah darah setiap hari. Penyebab paling sering responden tidak mengonsumsi tablet zat besi secara teratur atau rutin adalah lupa waktu karena waktu meminum tablet zat besi di malan hari (sebelum tidur). Hasil tersebut sesuai dengan temuan Subarda (2016) di Kabupaten Asahan yang menyatakan bahwa penyebab ibu hamil tidak rutin meminum tablet zat besi adalah lupa. ${ }^{18}$

Berdasarkan pembahasan diatas hasil penelitian ini tidak sejalan dengan upaya pemerintah untuk mencegah anemia pada ibu hamil yaitu melalui suplemen besi atau asam folat pada masa kehamilan sebanyak satu tablet setiap hari berturut-turut selama 90 hari pada masa kehamilan. Program tersebut bertujuan mencegah dan menangani masalah anemia pada masa kehamilan agar kadar hemoglobin meningkat secara cepat. Menurut Permenkes No 88 Tahun 2012 tentang standar tablet tambah darah bagi wanita usia subur dan ibu hamil, bahwa untuk melindungi wanita usia subur dan ibu hamil dari kekurangan gizi dan mencegah terjadinya anemia gizi besi maka perlu mengonsumsi tablet tambah darah. ${ }^{1,19}$

Selain karena lupa responden tidak patuh karena merasakan adanya keluhan setelah meminum tablet zat besi. Keluhan yang dirasakan merupakan efek samping tablet zat besi seperti mual muntah, diare, konstipasi, pusing dan sakit perut. Kondisi tersebut membuat beberapa responden merasa kondisinya semakin memburuk setelah mengonsumsi tablet zat besi. Temuan ini sesuai dengan penelitian irvina selain karena lupa $30,3 \%$ responden tidak patuh karena merasakan adanya keluhan setelah meminum tablet Fe. Sehingga menyebabkan responden memilih tidak melanjutkan meminum tablet Fe. ${ }^{9}$ KESIMPULAN

Berdasarkan hasil penelitian yang telah dikemukakan dapat disimpulkan sebagai berikut:

1) Konsumsi suplemen vitamin penambah darah oleh ibu hamil dari 110 ibu hamil di Kecamatan Jatinangor diperoleh sebanyak $13 \%$ responden tidak mengonsumsi suplemen vitamin penambah darah.

2) Karakteristik Suplemen vitamin penambah darah dari 96 ibu hamil yang mengonsumsi suplemen $100 \%$ menggunakan suplemen jenis kombinasi. tidak terdapat perbedaan antara bentuk sediaan yang disukai dan bentuk sediaan yang digunakan yaitu bentuk tablet.

3) Perilaku konsumsi suplemen hasil penelitian ini menunjukan sebagian besar responden mengonsumsi suplemen vitamin penambah darah pada kehamilan trimester 1, waktu meminum suplemen sebagian besar pada malam hari. Media yang paling sering digunakan adalah Air putih dan sudah sesuai dengan tata cara meminum tablet Fe.

4) Sebagian besar responden menunjukan bahwa informasi penggunaan suplemen vitamin penambah darah didapatkan dari bidan. Sebagian besar responden pernah lupa minum suplemen vitamin penambah darah. selain lupa responden tidak patuh karena merasakan adanya keluhan setelah meminum tablet zat besi.

\section{SARAN}

Berdasarkan hasil penelitian, pembahasan, dan kesimpulan maka dapat dikemukakan saran sebagai berikut:

1) Bagi tenaga kesehatan

Berdasarkan hasil penelitian diketahui bahwa sebagian besar responden kurang patuh dalam mengonsumsi suplemen vitamin penambah darah, untuk itu tenaga kesehatan diharapkan mampu melakukan peran khususnya bidan sebagai fasilitator dan pemberian pelayanan terdepan harus mampu memberikan informasi yang tepat kepada ibu hamil mengenai pentingnya Fe, cara mengonsumsinya dan kepatuhan dalam mengonsumsinya. 
2) Saran penelitian

Diharapkan bagi peneliti selanjutnya untuk melakukan penelitian mengenai keamanan dari kombinasi suplemen standar program pemerintah dengan suplemen lain untuk kehamilan.

\section{DAFTAR PUSTAKA}

Ahmed, A., \& Mohamed, E. (2015). Assessment of Iron and Calcium Supplements Compliance Among Pregnant Women Attending Antenatal Care Unit of AlSabah Banat Primary Health Care Unit in Ismailia, Egypt. Journal Of Medical And Biological Science Research, 1(3), 24-29.

Almatsier, S. (2010). Prinsip Dasar Ilmu Gizi. Jakarta: Gramedia Pustaka Utama.

Baharini, I. A., Pratama, A. N. W., \& Christianty, F. M. (2017). Hubungan Efek Samping Suplemen Zat Besi (Fe) dengan Kepatuhan Ibu Hamil di Puskesmas Sumbersari Kabupaten Jember. E-Journal Pustaka Kesehatan, 5(1), 35-39. https://doi.org/https://doi.org/10.19184/p k.v5i1.3946

BKKBN. (2011). Profil Hasil Pendataan Keluarga Tahun 2011. Jakarta: B a d a n Kependudukan dan Keluarga Berencana Nasional Direktorat Pelaporan dan Statistik.

Departemen Kesehatan RI Riskesdas. (2013). Laporan Hasil Riset Kesehatan Dasar Provinsi Jawa Tengah 2013. Jakarta: Badan Penelitian dan Pengembangan Kesehatan Kementrian Kesehatan RI. Retrieved $\begin{array}{llll}\mathrm{f} & \mathrm{r} & \mathrm{o} & \mathrm{m}\end{array}$ http://www.depkes.go.id/resources/dow nload/general/HasilRiskesdas2013.pdf

Dinas Kesehatan Sumedang. (2018). Profil Kesehatan Kabupaten Sumedang 2018. Jawa Barat: Dinkes.

H, P. S., Hapsari, D., Dharmayanti, I., \& Kusumawardani, N. (2015). FaktorFaktor yang Berpengaruh Terhadap Risiko Kehamilan 4 Terlalu (4-T) Pada Wanita Usia 10-59 Tahun (Analisis RISKESDAS 2010). Media Penelitian Dan
Pengembangan Kesehatan, 24(3), 143-152. https://doi.org/10.22435/mpk.v24i3.3649. 143-152

Handayani, L. (2013). Peran Petugas Kesehatan d a n Ke patuh a Ib u Hamil Mengkonsumsi Tablet Besi. Jurnal Kesehatan Masyarakat (Journal of Public Health), 7 ( 2 ). https://doi.org/10.12928/kesmas.v7i2.104 2

Kementerian Kesehatan RI. Peraturan Menteri Kesehatan tentang Standar Tablet Tambah Darah Bagi Wanita Usia Subur dan Ibu Hamil, Pub. L. No. Nomor 88 tahun 2014 (2014). Jakarta.

Marwati, Lestari, H., \& Afa, J. R. (2017). Hubungan Tingkat Asupan Energi, Protein, Zat Besi (Fe), Seng (Zn), Asam Folat, dan Vitamin A Ibu Hamil dengan Kejadian Berat Badan Lahir Bayi di Wilayah Kerja Puskesmas Puuwatu Kota Kendari Tahun 2017. Jurnal Ilmiah Mahasiswa Kesehatan Masyarakat, 2(7), $1-12$.

Puspitaningrum, D., Iskandar, F. N., \& Mulyati, L. (2013). Hubungan Antara Sikap Wanita Usia Subur (20-35 Tahun) Terhadap Perilaku Pencegahan Servitis dengan Pemeriksaan Skrining di Kelurahan Kalibanteng Kulon Lebdosari Semarang Tahun 2013. Jurnal Kebidanan Universitas Muhammadiyah Semarang, 2(2). https://doi.org/https://doi.org/10.26714/j k.2.2.2013.66-71

Ratnasari, A. D., Gunawan, I. M. A., \& Mursyid, A. (2017). Hubungan antara Kepatuhan Ibu Hamil Mengkonsumsi Tablet Fe, Asupan Fe, Protein dan Vitamin C dengan Kejadian Anemia di Puskesmas Kalasan. Jurnal Nutrisia, 19(1), 12-16. https://doi.org/10.29238/jnutri.v19i1.41

Rizki, F., Lipoeto, N. I., \& Ali, H. (2017). Hubungan Suplementasi Tablet Fe dengan Kadar Hemoglobin Pada Ibu Hamil Trimester III di Puskesmas Air Dingin Kota Padang. Jurnal Kesehatan Andalas, 6(3), 502-505. 
Rubio-Álvarez, A., Molina-Alarcón, M., \& Hernández-Martínez, A. (2018). Incidence of postpartum anaemia and risk factors associated with vaginal birth. Women and Birth, 31(3), 158-165. https://doi.org/10.1016/j.wombi.2017.09. 020

Septiani, W. (2017). Pelaksanaan Program Pemberian Tablet Zat Besi (Fe) pada Ibu Hamil. Journal of Midwifery Science, 1(2), 86-92.

Sinuhaji, O. S., \& Alfian, S. D. (2016). Artikel Review: Sumber Data dalam Farmakoepidemiologi. Farmaka, 14(2), $246-2 \quad \begin{array}{llll}2 & 6 & 3\end{array}$. https://doi.org/https://doi.org/10.24198/jf .v14i2.10839.g5173

Subarda, S., Hakimi, M., \& Helmyati, S. (2011). Pelayanan Antenatal Care dalam Pengelolaan Anemia Berhubungan dengan Kepatuhan Ibu Hamil Minum
Tablet Besi. Jurnal Gizi Klinik Indonesia, 8(1), 7.https://doi.org/10.22146/ijcn.17725

Susiloningtyas, I. (2012). Pemberian Zat Besi (Fe) dalam Kehamilan. Majalah Ilmiah Sultan Agung, 50(128), 73-99.

Ugwu, E., Olibe, A., Obi, S., \& Ugwu, A. (2014). Determinants of compliance to iron supplementation among pregnant women in Enugu, Southeastern Nigeria. Nigerian Journal of Clinical Practice, 17(5), 608. https://doi.org/10.4103/11193077.141427

Wahyuningsih, A., \& Kristanti, E. E. (2017). Konsumsi Suplemen Besi pada Ibu Hamil dengan Tingkat Kadar Hemoglobin. Jurnal Penelitian Keperawatan, 3(2), 71-78.

Young, M. F. (2018). Maternal Anaemia and Risk of Mortality: a Call for Action. The Lancet Global Health. https://doi.org/10.1016/S2214109X(18)30185-2 